\title{
Science Fiction as an Instructional Strategy: Foundations, Procedures, and Results for Pre-service Teachers
}

\author{
Oya Ağlarcı Özdemir ${ }^{1}\left[\right.$ [ $\cdot$ Fatma Önen Öztürk ${ }^{2}$ (])
}

Received: 8 February 2021 / Accepted: 8 December 2021 / Published online: 18 January 2022

(c) Ministry of Science and Technology, Taiwan 2021

\begin{abstract}
Science fiction (SF) combines realistic and imaginary elements of science and technology and develops students' imagination, creativity, and interest in science. Therefore, the aim of this study is to examine SF stories written by pre-service science teachers (PSTs) in terms of various textual and science variables. The case study of SF story writing aimed to develop a theoretical framework to analyze how narrative elements, plot structure, agency, the nature of science content, characteristics of the SF genre, and ethics in scientific research are included in the stories of a group of Turkish PSTs. The participants of the study were 58 pre-service teachers enrolled in the science education department at a public university in Turkey. Working in groups, they wrote 13 different SF stories. The stories were analyzed with a rubric including two parts: narrative and other story elements and the characteristics of the SF genre. The results showed that the stories included fictional and realistic features of science and technology, scientific concepts, and details about scientific realities. The stories addressed the social and cultural embeddedness of scientific knowledge and details about the scientific method. However, the originality is limited in many stories as they had traces from popular movies, books, and TV series. The stories did consider a range of ethical issues, including unauthorized experimentation and manipulating scientific information for personal, political, and financial interests. The current study could contribute to the literature about the use and assessment of SF stories in science education.
\end{abstract}

Keywords Nature of science $\cdot$ Science education $\cdot$ Science fiction story $\cdot$ Teacher education

Oya Ağlarcı Özdemir

oya.aglarci@marmara.edu.tr

1 Department of Chemistry Education, Atatürk Faculty of Education, Marmara University, İstanbul, Turkey

2 Department of Science Education, Atatürk Faculty of Education, Marmara University, İstanbul, Turkey 


\section{Introduction}

Science education must evolve over times to meet the needs of a changing world. Such changes often lead to reforms in the science curriculum and revisions of the ways science is taught and learned in many countries (Eilks \& Hofstein, 2017). At present, most countries aim to develop responsible citizenship in their society through education, and scientific literacy is an important aspect of this core outcome (Metin et al., 2020). The current science curricula of many countries (e.g., the USA, the UK, Taiwan, and Australia) include students' understanding of science and technology, nature of science (NOS), and inquiry skills (Kelly et al., 2020). Moreover, reform initiatives have generally called for changes to engage students in practices similar to those of working professional scientists (Namdar \& Shen, 2016). However, such curricula present a limited view of literacy skills and do not emphasize the epistemic, communicative, and rhetorical functions of language within and around science (Yore, 2018).

The science education curriculum in Turkey has undergone many reforms throughout the years. The current national science curriculum (Ministry of National Education, 2018) aims at scientific literacy and includes conceptual and theoretical scientific knowledge related to chemistry, biology, and physics, in addition to incorporating the NOS; socioscientific issues (SSIs), and values education into science learning. Students also need to experience science and engineering applications to increase their scientific and technological development. However, language and literacy skills are not explicitly reflected in the Turkish science curriculum, ignoring a fundamental aspect of scientific literacy that focuses on reading and writing science content.

Writing, talking, and reading about science are desirable goals of scientific literacy and offer ways of achieving such literacy (Hand et al., 2001). The application of student-generated narratives in science classes engages students by humanizing science (Fensham, 2001; Ritchie et al., 2011). Writing narratives has been proposed as a way to cultivate imagination in science teaching (Hadzigeorgiou et al., 2012). Narratives can be organized into several thematic categories, including SF which can bring both realistic and imaginary elements of science and technology into science classes. SF stimulates learners' interest in science and can be used as a powerful instructional tool in science education (Czerneda, 2006). Given the crucial role of language skills in science classes, this study examined SF stories written by Turkish PSTs in terms of textual and science variables. The importance of this study is twofold. First, the study incorporates the fundamental aspect of scientific literacy into science education through a story writing activity. Despite the potential benefits of using stories in science classes, there have been a limited number of studies investigating their utility (Williams \& Rudge, 2019). Second, the study sample consists of a group of PSTs. While they had not written a story in the SF genre before, this experience presented many learning opportunities for them. Indeed, PSTs have an important role in developing and assessing instructional practices for future science classrooms. Thus, such teachers should be engaged in activities that teach them how to write and use stories in their future classrooms during their education. 


\section{Scientific Literacy}

Scientific literacy has been a target outcome in science education for decades. The well-known definition of scientific literacy by the National Research Council (NRC, 1996) emphasizes the importance of scientific knowledge for both personal decision-making and public engagement in science. Later studies investigated in depth, giving a comprehensive perspective of the significance of science education for active citizenship. The Organization for Economic Co-operation and Development (OECD, 2016) described scientific literacy as "the ability to engage with science-related issues, and with the ideas of science, as a reflective citizen" (p. 20). Instead of a single definition, Roberts (2007) proposed a dual classification for scientific literacy encompassing two visions. The first vision (vision I) involves teaching the principles of natural sciences and subject matter knowledge; whereas, the second (vision II) focuses on the application of scientific knowledge in real-life science-related issues and involves the relationship between science, technology, and society. While these definitions and visions represent important aspects of scientific literacy, they do not include the essential roles of language and literacy in science education. Yore (2012) proposed a third vision of scientific literacy, named vision III of scientific literacy for all which underscores the fundamental aspect of scientific literacy. He stated that vision III is composed of "two interactive clusters of cognitive, affective, communicative, and technological abilities related to science - the fundamental sense of being a literate person in science-and knowledge of science and the scientific enterprise-derived sense of understandings flowing from human endeavors related to nature and naturally occurring events that allow for fuller participation and engagement of science in a social context" (p. 7).

In light of the fact that very few science education policies or curriculum recognize literacy skills as a critical component of scientific literacy, Norris and Phillips (2003) suggested that literacy and language skills are fundamental for scientific practice. Scientific literacy can be defined in two aspects: the derived sense and the fundamental sense. The derived sense involves being knowledgeable and educated in science. On the other hand, reading and writing comprise the fundamental sense of scientific literacy; one cannot perform science without knowing the language that underpins it. As such, the fundamental sense of scientific literacy encompasses all scientific language, including speaking-listening, writing-reading, representing-interpreting, and enterprise terms as well as individuals' cognitive/ metacognitive abilities, emotional dispositions/habits of mind, attitudes, and critical thinking (Yore, 2018). The fundamental and derived senses of scientific literacy engage science, technology, society, and environmental (STSE) issues (Hand \& Prain, 2006; Yore, 2012), which brings up the third sense. Recently, citizen participation sense has been proposed as an applied component, which involves both the fundamental and derived senses. It requires informed and active citizenship in the consideration of STSE issues to make informed decisions and produce sustainable solutions (Yore, 2018). Considering the vital importance of citizens' decisions on these issues, the applied component of scientific literacy has become more meaningful than ever. 


\section{Using Language Arts to Learn Science}

There have been many attempts at interdisciplinary approaches to integrate science and literacy into science education (e.g., Hand et al., 2003; Norris \& Phillips, 2003; Yore, 2018). Language in the form of written texts, spoken words, and figural representations is essential for learning in all science classrooms (Fulmer et al., 2021). Moreover, language not only includes reading and writing about science, but also comprehension, metacognition, alternative texts, writing, and inquiry (Yore et al., 2003). Language determines the kind(s) of learning experiences that learners can engage with (Hand et al., 2019). The NRC's (2012) Framework document states, "every science or engineering lesson is in part a language lesson ... [because] students should be able to interpret meaning from text, to produce text in which written language and diagrams are used to express scientific ideas and to engage in extended discussion about those ideas" (p. 76). Linking science with literacy skills enhances students' motivation and interest in using language to ask questions and understand the world (Freeman \& Taylor, 2006). As such, writing is a critical tool for scientific literacy and inquiry (Yore \& Treagust, 2006). Students write to develop a conceptual understanding of science and to socialize into the science community (Choi et al., 2010; Gunel et al., 2007; Hand \& Prain, 2002). Writing also helps students develop the mindset and habits of scientists who work within the scientific discipline (Pytash, 2013). In an earlier study, Halliday and Martin (2003) suggested that students could not learn science before learning the genres of writing used by scientists. They proposed that students should learn about the languages of science by using them to live these languages.

Theorists espouse two different perspectives about the types of writing practices that should occur in science education: traditional and nontraditional (Prain, 2006). The traditional perspective focuses on record keeping, laboratory reports, and assessment writing, while the nontraditional approach encompasses a wider range of genres, such as narratives, descriptions, explanations, and argumentation (Pytash, 2013). These different writing tasks, especially imaginative and creative writing, have been proven to improve students' learning outcomes, attitudes, and engagement in science (e.g., Hand \& Prain, 2002; Ritchie et al., 2011). Narratives are among the most powerful learning and teaching tools in science education (Avraamidou \& Osborne, 2009; Murmann \& Avraamidou, 2014), as they can relate creative narrative thinking and logical scientific thinking. At the same time, narratives enable students to develop the types of values, attitudes, and behaviors demanded of today's democratic citizenry (Vrasidas et al., 2015).

\section{SF as High-Interest Genre}

SF examines the role, relevance, and advantages of present and future technologies and provides ideas that can affect people's opinions on these matters (Menadue \& Cheer, 2017). In addition to exploring the nature of future societies and future technologies (Selwyn et al., 2020), SF also provides a historical record of changes in 
social and cultural values over time (Menadue, 2017). One of the most well-known examples of the genre, Frankenstein; or, The Modern Prometheus, is accepted as the first contemporary SF work. Its author, Mary Shelley, was fascinated by early experiments with electricity and Galvanism, as well as Volta's invention of the battery (Sha, 2012). The French writer Jules Verne and the English writer H. G. Wells are two of the most famous SF authors of the 19th century (Roberts, 2006). These authors were influenced by the scientific advances of the period and were able to predict the technological developments of the future, making great contributions to the literary genre. The first English-language magazine entirely devoted to SF was Hugo Gernsback's Amazing Stories, founded in 1926. This represented the first attempt to define the genre, which the editor called scientifiction at the beginning, but later referred to as science fiction (Attebery, 2003). Major SF themes include utopias and dystopias, alternative societies, sex and gender, alien encounters, space and time travel, alternate histories and parallel universes, and high technologies (Sterling, 2021).

Using the SF genre for instructional purposes has become increasingly popular in recent years (Orthia, 2015). SF activities address issues related to how science functions, thus providing basic building blocks of scientific literacy (Czerneda, 2006). Moreover, the inclusion of SF in science classes can enhance students' research and critical analysis skills (Putt, 2011). The SF genre can be used to teach social elements of science, as well as ethics and controversial issues in science and technology, providing an instructional resource that can represent science within a human context (Orthia, 2015) and enhance students' imagination and creativity (Vrasidas et al., 2015). Thus, SF and the topics it addresses can be used to grow students' interest in science. Studies in science education have shown that using the SF genre for teaching is quite effective and offers a valuable context for classroom practice (e.g., Bixler, 2007; Liberko, 2004; Önen Öztürk, 2017; Surmeli, 2012). Integrating SF for instructional purposes in science classes can involve movies (e.g., Barnett \& Kafka, 2007; Bixler, 2007; Surmeli, 2012), stories (e.g., Reis \& Galvão, 2004, 2007; Vrasidas et al., 2015), and novels (e.g., Liberko, 2004). In their studies with students, Reis and Galvão (2004) used SF stories to help identify and gauge students' conceptions of scientists. The researchers explained that such stories can present that science is not solely limited to theories and facts-it also includes social and cultural aspects of today's world. In another study, Reis and Galvão (2007) identified high school students' stereotypical images about scientists through studies of SF stories. The students' stories helped them to construct a more realistic image of science and technology and its interactions with the sociocultural context. A later study (Vrasidas et al., 2015) explored the results from the implementation of a project in primary schools in five countries. The project aimed to provide teachers training and teaching materials on SF narratives to assist them in enhancing their science teaching. The study results indicate SF's great potential, as the narratives supported students' learning and engagement with science. However, the teachers faced difficulties during implementation for various reasons, including the nature of the centralized school curriculum (the activities used in the project were interdisciplinary), availability of resources, and time required to design stories and integrate SF into the classroom. A lack of time posed the biggest challenge for the teachers; they also 
needed more materials and resources to include SF in their classrooms. The project demonstrated that teachers need time, effort, experience, and creativity to integrate SF stories into lesson plans and that students need writing instruction in their science classrooms to become effective communicators. Therefore, PSTs need instruction during their university education on how to write and how to teach writing. Writing SF stories could provide an important experience for PSTs because it can help them to reflect their views about science and promote imagination and creativity in their classrooms.

Thus, the aim of this study is to examine SF stories written by PSTs in terms of various textual and science variables. The study addresses the following research questions (RQs):

1. How are narrative elements, plot structure, agency, and the NOS content included in SF stories written by PSTs?

2. How are the characteristics of the SF genre included in these stories?

3. How are ethics in scientific research included in these stories?

\section{Method}

This case study of SF story writing was designed to "investigate a contemporary phenomenon within its real-life context, especially when the boundaries between phenomenon and context are not clearly evident" (Yin, 2003, p. 13). We aimed to develop a theoretical framework and rubric to analyze how narrative elements, plot structure, agency, the NOS content, characteristics of the SF genre, and ethics in scientific research are included in the SF stories of a group of Turkish PSTs. The research and development (R\&D) approach (van den Akker, 1999) can improve the instructional design in teacher education. Therefore, studies aiming to improve instructional design should consider the $R \& D$ approach to be more appropriate than a typical scientific research inquiry method (Anthony et al., 2010) when identifying how the SF genre could be incorporated for instructional purposes in science education.

\section{Participants}

The sample in this study was comprised of 58 pre-service teachers (56 females and 2 males, ranging 18-22 years in age) enrolled in the science education program at a public university in Turkey. Participants were sophomore students enrolled in a second-year course of a 4-year program involving theoretical courses, laboratory practices, and clinical teaching experiences. The participants volunteered for the study after being informed about the general purpose and requirements of the research. Before the study, the participants had taken theoretical courses in physics, chemistry, biology, and pedagogy. 


\section{Context of the Course}

The research was carried out in the 14-week, 3-credit-hour Science, Technology, and Society course taught by one of the authors of the study. The course aimed to develop students' understanding of the STSE issues and to investigate aspects of scientific knowledge and studies from cultural, ethical, and philosophical perspectives. Therefore, the course had an interdisciplinary character and covered topics such as the STSE issues; differences in traditional and post-modern understandings of science; the distinction between science and pseudo-science; SSIs; media and its role in science education; the SF genre; educational short films.

$\mathrm{SF}$ stories were discussed in detail as a part of the course. The instructor gave detailed information about the SF genre, the impact of SF stories on science education, and the relationship between science education and narratives. SF stories generally include a certain set of narrative and fictional elements and character archetypes that are specific to the SF genre. The instructor introduced a story framework including all these elements to the PSTs before the writing activity. The PSTs worked as a group to write SF stories, to create a collaborative and creative environment. The instructor did not assign the group members, instead allowing the students to form their own groups. The participants formed 13 groups in total, with 3-6 members each. They were given 3 weeks to complete their writing. Participants were first asked to think about possible story approaches while investigating scientific and technological concepts that they could include. The stories were expected to be original, with no page or word limit, and needed to be compatible with the current curriculum so they could serve as instructional materials in science classes. The stories touched upon the general scientific disciplines of biology, physics, and chemistry and included some advanced scientific concepts and theories (e.g., telomeres, genetic mutation, retina scanning - topics covered in the university science curriculum but not in the middle school curriculum). They wrote the stories based on their interests within the curricular topics. Accordingly, each group constructed a plot and characters, incorporating SF content and technological concepts. A week after the project began, the groups were asked to present and discuss their initial ideas and story drafts with the class and instructor. In this session, they were expected to present the main elements of their stories (story grammar), including setting, problem, plot development, and characters. There were two purposes for this discussion: first, to provide an opportunity for interventions if the stories were too similar; and second, to correct logical errors and problematic plot elements by referring to the story framework. At the end of the writing period, each group presented their story in the classroom. Finally, the research team analyzed the SF stories, as discussed in the next section.

\section{Data Analysis}

The SF stories were analyzed according to a two-part rubric. The first part of the rubric was used to identify and analyze the narrative and other story elements, 
Table 1 First part of the rubric: narrative elements, plot structure, agency, and the NOS content in the stories (adapted from Klassen \& Froese Klassen, 2014a, b)

General story elements $\quad$ Scoring criteria

1. Narrative elements (characters, Characters are inconsistent and unclear. Narrative elements in the actions, situations, consequential story are very limited to understanding. Time is inconsistent. coherence, time) (Inadequate)

Characters are clear, but no details are given. Narrative elements are clear. Time is consistent. (Proficient)

Characters are strongly established. Actions, situations, and consequential coherence are well-written. The narrative is written in the past tense, and the included scientific knowledge is written in the present tense. (Advanced)

2. Plot structure (setting the scene, The plot structure is not well established. The introduction and the problematic situation, crisis, critical conclusion are not very satisfying. The crisis and/or the critical decision, climax, conclusion) choice by the character are absent. The story lacks a climax. The problematic situation is not resolved in the conclusion. (Inadequate)

The plot structure is clear. However, it is not impressive or very well written. The conclusion is clear; however, it is not satisfying (Proficient)

The plot structure is well-constructed. There is an interesting introduction and a satisfying conclusion. The problematic situation and the crisis that the characters faced are written interestingly. The story has a logical climax. The problem is resolved negatively or positively in the conclusion. (Advanced)

3. Agency

No agency of a character (Inadequate)

The character has agency; however, it is not well-established (Proficient)

Well-established agency (Advanced)

4. The NOS content

No aspects of NOS are depicted in the story (Inadequate)

1 aspect of NOS is depicted in the story (Proficient)

More than 1 aspect of NOS is depicted in the story (Advanced)

while the second part assessed the characteristics of the SF genre. We used the tertiary ordinal coding process (inadequate, proficient, and advanced) for the performance categories in both parts of the rubric. The first part of the rubric (Table 1) employed Klassen and Froese Klassen's (2014a, b) framework for designing, writing, and analyzing science stories.

The performance categories in the first part of the rubric include:

1. Narrative elements: The following 5 elements serve as a story framework for constructing and writing SF stories.

- Characters: The main character is involved in the story, and his/her actions lead the story. Moreover, all the characters are strongly drawn: details about their physical appearances, actions, and thoughts are given in detail in an advanced story. 
- Actions: The actions of the characters could happen in a fictional and/or realworld (e.g., somebody is doing something physically or mentally, and it leads to other actions). The actions should be plausible in an advanced story.

- Situations: There are situations that the characters react/respond to or that they help to create.

- Consequential coherence: Actions and situations are consequentially connected. One action leads to another; either directly or indirectly.

- Time: The events take place in the past and are recounted (by a narrator), or they take place in a future time. The time of the story, whether it takes place in the past or future, is expected to be clearly described. In an advanced story, narrative parts of the story are written in the past tense, whereas the included scientific knowledge and facts are expository and written in the present tense (e.g., "the vehicles that they called cars were now exhibited in museums (past tense-narrative)...the scientist noticed (past tense-narrative) that when the two elements combine, they form a new chemical compound with a high molecular weight (present tense-scientific knowledge).

2. Plot structure: The following 6 elements refer to the sequence of the events in SF stories.

- Setting the scene: An introduction,

- A problematic situation: A problem related to a scientific phenomenon,

- A crisis: The main character has to do something because the problem reaches a critical level,

- A critical decision: The main character makes an important choice,

- The climax: The story reaches a turning point, after that the events become better or worse,

- The conclusion: The problematic situation is resolved either positively or negatively.

3. Agency: The result of the story relies on a critical decision or decisions made by the main character.

4. The NOS content: According to Klassen and Froese Klassen's framework, SF stories should contain science and NOS content. Consequently, we aimed to analyze the NOS content in-depth by including Lederman et al.'s (2002) NOS framework in the analysis. This framework highlights an academic consensus on the aspects of the NOS that should be included in school science. These aspects include the empirical, creative and imaginative, theory-laden, and tentative NOS, in addition to the social and cultural embeddedness of scientific knowledge, observation, inference, and theoretical entities in science, scientific theories and laws, and the scientific method. Each story was analyzed for depictions of these aspects of NOS. If none of the aforementioned aspects were addressed, the story was 
considered "inadequate" in terms of NOS content. If a single NOS aspect was included, the story was considered "proficient," and if they are more than one aspect was present, the story was considered "advanced."

The second part of the rubric assesses the characteristics of the SF genre exhibited by the stories (Table 2). These characteristics were based on the relevant literature on the SF genre (e.g., Czerneda, 2006; Reis \& Galvao, 2007).

SF stories generally include scientific facts and concepts as well as fictional and technological elements. Fictional and imaginary elements in SF stories differentiate them from science stories in general. We sought an expert opinion after developing the second part of the rubric. An expert with a Ph.D. in science education examined the rubric and his opinions were taken into consideration before the final version of the rubric was constructed. He and the research team reached a consensus on the items of the rubric to be used. An advanced SF story includes multiple important characteristics, including SF-specific content (e.g., characters or entities with fantastic and surrealistic features, parallel universes, space-time travel, extra-terrestrials, and inventions or experiments that spiral out of control), the originality of the stories, and the impact of science and technology on society.

The stories underwent a process of content analysis. The basic process in the content analysis involves grouping and categorizing data within the framework of certain concepts and themes before interpreting them by organizing them in a way that the reader can understand (Corbin \& Strauss, 2014). By re-reading the stories and applying the rubric, additional categories emerged: the field(s) of science the stories related to (e.g., a biology-related story), the scientific and technological concepts used in the stories (which gave further information about the elements in the second part of the rubric), and details about research ethics. Ethics in scientific research emerged as a category because some of the stories included details about scientists complying (or failing to comply) with ethical principles.

It is important to establish an inter-coder agreement in qualitative research analysis to ensure validity, reliability, and trustworthiness; thus, multiple coders analyzed the SF stories independently for this study. First, two members of the research team independently analyzed the stories and then compared their analysis. The rate of agreement of their analysis was calculated as $90 \%$. The disagreements between them were then resolved by negotiating until they reached a consensus. Additionally, two other independent researchers with expertise in science education analyzed the stories. These researchers first studied the rubric and were given additional information about the analysis procedure, before separately analyzing the stories. While there were some discrepancies (the intercoder agreement rate of the coders was $85 \%$ ), all the researchers reached joint decisions after discussing their codes and reaching a consensus. By utilizing the negotiated agreement approach (Campbell et al., 2013), the coders compared their codes and then discussed the disagreements to reconcile them and reach a final decision that resolved all discrepancies. 
Table 2 Second part of the rubric: the characteristics of the SF genre in the stories

The characteristics of the SF genre
Characteristics related to science and technol
The impact of science and technology on socie
Content of SF genre (e.g., parallel universes,
space-time travel, etc.)
space-time travel, etc.)

Details related to scientific reality

Based on scientific explanation and theories

Originality of the story (shows the imagination and creativity of the writer)

Scientific concepts

Technological concepts
Scoring criteria

The story does not include any characteristics related to science and technology (Inadequate)

The story includes one or a few characteristics related to science and technology (Proficient)

The story includes several characteristics related to science and technology (Advanced)

The impact of science and technology on society is not mentioned (Inadequate)

Only one thing is mentioned related to the impact of science and technology on society (Proficient)

The impact of science and technology on society is well covered (Advanced)

Content elements of the SF genre are not included (Inadequate)

Only one or a few of the content elements of the SF genre are included (Proficient)

Several content elements of the SF genre are included (Advanced)

There are no details related to scientific reality (Inadequate)

Details related to scientific reality are not given aligned with the content (Proficient)

There are details related to the scientific reality that correspond well with the content (Advanced)

The story content is not based on any scientific explanation or theories (Inadequate)

The story content is not appropriate based on scientific explanation and theories (Proficient)

The story content is based appropriately on scientific explanation and theories (Advanced)

The story does not show the writer's imagination and is not original (Inadequate)

The story shows the writer's imagination and/or is partly original (Proficient)

The story shows the writer's imagination and is original (Advanced)

There are only one or a few scientific concepts aligned with the story content-no additional explanation is given related to the concept(s) (Inadequate)

There are a few scientific concepts aligned with the story content (Proficient)

There are several scientific concepts aligned with the story content (Advanced)

There are only one or a few technological concepts aligned with the story content - no additional explanation is given related to the concept(s) (Inadequate)

The story content appropriately includes a few technological concepts (Proficient)

The story content includes a satisfactory number of technological concepts (Advanced) 
Table 3 Names and storylines of the SF stories

\begin{tabular}{|c|c|}
\hline Name of the story & Storylines \\
\hline "NEO Prophecy" & $\begin{array}{l}\text { Archaeological excavation and the struggle of humans with a new species } \\
\text { called NEO that emerged after the excavation }\end{array}$ \\
\hline "Russian Team" & Power struggle between children with special powers \\
\hline "Manipulator" & $\begin{array}{l}\text { The unexpected negative consequences of extending humanity's lifespan by a } \\
\text { genetic mutation (thus worsening people's living conditions) }\end{array}$ \\
\hline "Longing for Alistair" & Time travel of a scientist who wants to reunite with his deceased wife \\
\hline "Biological Weapon" & Biological warfare between two countries and the role of scientists in this war \\
\hline "Recurrence" & The end of an era on earth with the discovery of a new chemical element \\
\hline "From Future to Past" & $\begin{array}{l}\text { In the future time, a group of scientists try to survive in an environment } \\
\text { without technology }\end{array}$ \\
\hline "Star Nightmare" & $\begin{array}{l}\text { The impact of epidemic disease on human life resulting from an explosion in } \\
\text { space }\end{array}$ \\
\hline "The Future in The Past" & $\begin{array}{l}\text { A time-traveling student realizes that some past events are repeated in the } \\
\text { future }\end{array}$ \\
\hline "A Strange Story" & $\begin{array}{l}\text { An alien takes a boy from earth to its home planet and shows him how life on } \\
\text { earth will end }\end{array}$ \\
\hline "From Turkey to Mars" & $\begin{array}{l}\text { A researcher discovers life on Mars even though she is not supported by her } \\
\text { colleagues }\end{array}$ \\
\hline "Blue Nightmare" & $\begin{array}{l}\text { A girl gains a superpower after an accident in the lab and becomes a super- } \\
\text { hero who turns blue at night }\end{array}$ \\
\hline "The Apprentice" & $\begin{array}{l}\text { A girl with special powers learns some hidden truths to become a leader in an } \\
\text { underground civilization }\end{array}$ \\
\hline
\end{tabular}

\section{Results}

The results from the analysis of SF stories are presented as follows: the RQs are presented in boldface type, the assertations constructed from the stories are presented in normal type, illustrative quotes from the stories (to serve as evidence) are presented in italic type and authors' explanations are presented in normal type.

RQ 1. How are narrative elements, plot structure, agency, and the NOS content included in SF stories written by PSTs?

The stories mainly presented the positive and negative consequences of science and technology. While illustrating both fictional and realistic features of science and technology, the stories reflected how the characters (e.g., scientists and members of society) reacted to unfolding situations and circumstances. The names and storylines of the SF stories are presented in Table 3.

The stories mainly have inadequate plot structures, reasonable progress of narrative elements and agencies, and good development of the NOS. The frequency (f) and percentage (\%) analysis of the narrative elements, plot structure, agency, and the NOS content in the SF stories are presented in Table 4 and illustrated through direct quotations and depictions (explanations of the stories) in accordance with qualitative research best practices. 
Table 4 The narrative elements, plot structure, agency, and the NOS content

\begin{tabular}{rlll}
\hline & Inadequate $(f-\%)$ & Proficient $(f-\%)$ & Advanced $(f-\%)$ \\
\hline Narrative elements & $1-8 \%$ & $7-54 \%$ & $5-38 \%$ \\
Plot structure & $10-77 \%$ & - & $3-23 \%$ \\
Agency & $2-15 \%$ & $6-46 \%$ & $5-38 \%$ \\
The NOS content & $4-31 \%$ & - & $9-69 \%$ \\
\hline
\end{tabular}

The variation in the quality across the stories produced three categories including inadequate, proficient, and advanced. In the following, three quotations were selected to present the evaluation of narrative elements from inadequate to advanced.

"Doctor Hannah is a scientist who lives in a small city and is interested in life in space. Her interest in space prompts her to do research. Her research was creating problems in her mind...after that, her path got easier. The space-age had begun. The doctor's work set an example for young researchers." ("From Turkey to Mars" - An inadequate story in terms of narrative elements)

Dr. Hannah was not adequately explained to the readers, and the actions and situations that she was involved in did not affect the story. All the characters in this story were inconsistent and unclear, and the plot was quite inconsistent and provided the readers with a limited understanding of what was going on. No details were provided that explained how Dr. Hannah carried out her research without any support. The timeline of the story was also inconsistent, as the story began in the present tense and ended in the past tense.

"Eight scientists, working without sleep for 48 hours, finally synthesized the virus. But they had no idea that the virus would be used as a biological weapon... They found a cure for the virus using organisms created by mutations and artificial transplantation. All people struggling with the disease were vaccinated. Surprised by the ineffectiveness of the biological weapon, the country expelled scientists from the country. However, the scientists started a new life in a different country." ("Biological Weapon" - A proficient story in terms of narrative elements)

This story adequately outlined the actions and situations that the characters both created and responded to. However, no details related to the characters and their aims were provided. None of the characters were clearly developed.

"Tom was a curious, excited, inquisitive, and intelligent boy who lived his life quite complex and full of fun. He didn't like to play with race cars like his peers. He wanted to discover new things and find solutions to the environmental problems of the city he lived in. This problem had been the meaning of his life...The alien took Tom to its home planet to show the future end of the world. Tom could not believe what the alien was showing. How did humanity devastate the world like this?" ("A Strange Story" - An advanced story in terms of narrative elements)

The main character, Tom, and his friend alien were both well-established characters. Tom was curious, and the alien was very determined to help him by showing him the end of the Earth. The writers of the story presented readers with characters whose actions lead the story. The main character experienced a situation (his 
abduction and awareness about the end of the world) that he had to respond to. Moreover, the events were consistently described in the past tense.

The following two exemplars illustrate the evaluation categories (inadequate and advanced) for the plot structure category. No proficient examples were found in this category. They are given with authors' explanations instead of direct quotations in order to present the categories in a more descriptive way.

The story "Biological Weapon" exhibited an inadequate plot structure. The introduction to the story described the scientists' work on biological weapons and the political conflict between countries. Later, the narrative focused on a love story between one of the scientists and a citizen of the opposing country. The scientist produced a vaccine to save his lover and his country. The plot structure was not well established, as a connection could not be properly established between the introduction and the crisis at hand. Even though the critical decision made by the character was explained, the conclusion did not contain details about the resolution.

"The Star Nightmare" demonstrated advanced plot structure. This story focused on an incident that a doctor saw in a dream. In his home, the doctor found a box and a notebook with a star-shaped seal that he could not open. Afterward, when visiting the hospital where he worked, he realized many patients with serious health problems stemming from their blood cells transforming into a star-shaped structuremany of whom died. The doctor then realized that the blood cells resembled the seal on the notebook. A colleague managed to open the seal and discovered that the notebook had belonged to the doctor's grandfather, who was an astronomer. By following the instructions in the notebook, they found a cure to save the patients. The plot structure of the story was well constructed, with an interesting introduction and satisfying conclusion. The problematic situation and the crisis that the characters faced were compellingly written.

The following three exemplars illustrate the evaluation categories (inadequate, proficient, and advanced) for the agency category. They are presented with authors' explanations instead of direct quotations. The story entitled "The Future in the Past" was inadequate in terms of agency. The main character made no critical decisions; he was just an observer in the story. The story entitled "Biological Weapon" demonstrated proficient agency. There were no main characters in the story. Although the characters (eight scientists) made critical decisions, the impact of these choices was not well reflected in the story. The story entitled "Longing for Alistair" exhibited advanced agency, according to the rubric. The main character, a scientist, sought to reunite with his wife, who passed away in a car accident. He traveled to the past and returned to the day of the accident. The character demonstrated strong agency, which affected the nature of the story.

Four of the stories ("Recurrence," "The Future in The Past," "A Strange Story," and "Blue Nightmare") exhibited no considerations of the NOS and were inadequate. The other nine stories exhibited more than one aspect of NOS and were advanced $^{1}$. These stories addressed the following issues: the scientific method ( 8

\footnotetext{
1 The NOS aspects depicted in SF stories are presented in Electronic Supplementary Material 1 (ESM $1)$.
} 
stories); the social and cultural embeddedness of scientific knowledge (7 stories); observation, inference, and theoretical entities in science ( 5 stories); the empirical NOS (2 stories); the theory-laden NOS (2 stories); and the creative and imaginative NOS (1 story). Selected quotes reflecting the NOS aspects in the stories are given below.

“... She talked about her aims and the experiments to the country's notable scientists. She believed that they would achieve successful results with a hardworking research team. Many scientists claimed that observations about aliens were made beforehand, but no conclusion was reached. They said that it was a futile effort to investigate. Therefore, they refused the doctor's proposal and did not support her. However, the doctor did not despair. She started her experiments by recruiting a small team of diligent people who believed in her and valued her aims... After thousands of tries, they got results and developed a magnet and a machine that would maximize the magnetic effect..." (the social and cultural embeddedness of scientific knowledge, "From Turkey to Mars")

"...After graduating from university, Samantha was chosen to the archaeological excavation team. The team consisted of eight people; including researchers from other countries...Johnson went on looking absently, looking as if he had seen something away for about two seconds: "I understood that he reached some conclusions from his observations, but he must have buried it because he was afraid of the church. I still do not understand how he came to such an inference based on his observations, maybe we can find it (the answer) in the other tablets..." (observation, inference, and theoretical entities in science; social and cultural embeddedness of scientific knowledge, "NEO Prophecy")

"As Johnson went the trailer to examine the tablets, he turned excitedly and shouted to the team: 'Hey Merle! You come with me'... Samantha and her team were unaware of what was going on. Johnson asked her for help in writing the reports of the tablets that he had discovered. They worked until the morning, and the results were very interesting. Truly it was a prophecy and meant NEOs would have destroyed the Earth. He immediately sent an e-mail to the university. Moreover, they reached the date of December 21, 2016, from their analysis on tablets." (the scientific method, "NEO Prophecy")

Many stories contained details about components of the scientific method, such as data collection, experimentation, observation, inferences, and making conclusions. These stories reflected that the PSTs did not have misconceptions related to the "universal" scientific method. In addition, the stories included details about the social and cultural embeddedness of scientific knowledge, such as scientists working together and being influenced by each other, as well as economic, cultural, and religious factors affecting science. This result might be an indicator that the course was effective in developing the views about the social and cultural values in science as the course focused on STSE issues.

RQ2. How are the characteristics of the SF genre included in these stories?

The stories contained a binary pattern (inadequate vs. advanced) of science characteristics, with only three traits being demonstrated as advanced qualities and five traits being demonstrated as inadequate qualities. Table 5 provides the 
Table 5 The characteristics of the SF genre

\begin{tabular}{llll}
\hline The characteristics & Inadequate $(f-\%)$ & Proficient $(f-\%)$ & Advanced $(f-\%)$ \\
\hline Characteristics related to science and technology & $7-54 \%$ & $3-23 \%$ & $3-23 \%$ \\
The impact of science and technology on society & $1-8 \%$ & $3-23 \%$ & $9-69 \%$ \\
Content of SF genre & $9-69 \%$ & $2-15 \%$ & $2-15 \%$ \\
Details related to scientific reality & $3-23 \%$ & - & $10-77 \%$ \\
Based on scientific explanation and theories & $9-69 \%$ & - & $4-31 \%$ \\
Originality of the story & $10-77 \%$ & $2-15 \%$ & $1-8 \%$ \\
Scientific concepts & $3-23 \%$ & $2-15 \%$ & $8-62 \%$ \\
Technological concepts & $8-62 \%$ & $1-8 \%$ & $4-31 \%$ \\
\hline
\end{tabular}

frequency (f) and percentage (\%) distributions of the stories across the inadequate, proficient, and advanced categories for the eight characteristics of the SF genre $^{2}$.

Most of the stories $(n=7)$ displayed inadequate characteristics related to science and technology. However, nine of the stories demonstrated advanced inclusion of the impact of science and technology on society. Although most of the stories ( $n$ $=10)$ provided details on scientific reality, the majority $(n=9)$ were not based on scientific explanations or theories. As such, most of the stories $(n=9)$ contained inadequate content specific to SF. All the stories seemed to include SF content, such as imaginary characters, space-time journeys, and parallel universes; however, these aspects were not handled in detail but rather mentioned in a cursory manner. The participants did not establish the necessary relationship between these aspects and the plot. Interestingly, many of the stories lacked originality $(n=10)$. These stories had traces from popular movies, books, and television series such as Arrival, X-Men, Iron Man, Back to the Future, The Hunger Games, and the Divergent series, demonstrating only minor differences in terms of plot and characters.

Most of the stories $(n=8)$ were advanced in terms of the scientific concepts they included $^{3}$. The scientific concepts reflected in the stories largely came from the middle school science curriculum; though some advanced scientific concepts from the university science curriculum were also integrated into the narratives. The PSTs mostly wrote stories about biology, though some also incorporated the fields of physics, astronomy, geology, and chemistry. Therefore, the scientific concepts differed according to the storylines, as well as the field(s) of science that the narratives focused on. While concepts such as drugs, the genetic code, cells, tissues, and viruses were used in stories related to biology, concepts such as earthquakes, earth, and excavation were used in stories related to geology. Generally, the concepts in each story corresponded well with the story's focus. Furthermore, these concepts

\footnotetext{
2 Illustrative analysis of the characteristics of the SF genre is presented in ESM 2.

3 The list of the scientific and technological concepts in the SF stories are presented in ESM 3.
} 
were typically defined and represented correctly. Examples of the use of scientific concepts in the stories are provided below.

“...He was a crazy man, even a lunatic man, according to some, and he had done many works for the scientific world. Alistair developed some extraordinary theories and he was a scientist who applied them. Some even raised the thoughts that he travels in time' for him, Einstein mentioned that the journey in time would be possible. This made Doctor John remember this theory. From 10 am to 11 am, if an object reaches a speed greater than the speed of light, the timeline may be twisted. When the two ends are combined, a tremendous amount of energy is needed to absorb the bounce. He said that he could travel no more than twelve hours, and that the error was caused by using a wrong polynomial. He went to another lab and changed the degree of the equation there and returned to the day of the accident..." ("Longing for Alistair")

Many of the stories $(n=8)$ contained an inadequate number of technological concepts. At least one technological concept was included in each story, although they were not as diverse as the scientific concepts that were used. Some of the stories employed imaginary technologies, such as new inventions, but the content of the inventions and their mechanisms of operation were not explained properly. Other stories referred to various current technologies (such as computers, cars, and vaccines) which were used without making any connection with the storyline and fictional characteristics. Examples of the technological concepts in the stories are given below:

"...The machines that they named cars in the past are now in our museums... there are a few aircraft and planes left from the past. If we manage to operate them, we can easily go to the places we want. We try to find internet networks created in the past. We think there is a lot of information there...Fresh air comes from the ventilation every hour. There is no single light here except artificial light. There is a different button all over the room. These people don't do any of their own work..." ("From Future to Past")

\section{RQ3. How are ethics in scientific research included in these stories?}

Six of the stories ("NEO Prophecy," "Star Nightmare," "The Future in The Past," "A Strange Story," "From Turkey to Mars," and "Blue Nightmare") did not touch on any ethical issues, while the seven others considered a range of ethical questions. These issues included unauthorized experimentation on children and innocents ("Russian Team," "Longing for Alistair"); hiding, stealing, and/or controlling scientific information ("Manipulator," "The Apprentice"); and using scientific/technological information (with malicious intent) for personal ("Longing for Alistair," "From Future to Past"), political ("Biological Weapon"), and financial gain ("Recurrence"). Examples from the stories reflecting these ethical issues are provided below.

“...The program was professor's secret project where children taken from an orphanage were raised in a region of Russia unknown to humans, and children gained superhuman characteristics by injecting a special power drug prepared by the professor..." (unauthorized experimentation on children, "Russian Team")

"Alistar was a scientist who did extraordinary experiments and applied his theories in real life. Some even claimed that he traveled through time... That specific day, something extraordinary happened on the train. One man just disappeared and 
all the people on the train died at the same time. How could this happen? (In the continuation of the story, it is revealed that Alistair conducted his experiment (which required high energy) in public areas and caused the death of people by using his scientific studies to reunite with his wife unauthorized experimentation on people "Longing for Alistair")

"...So can you hide this information from them? Or can you lie to people? You have to lie! Do you have any idea what will happen when they hear that we are trapped here, that no one will get out of here for at least 100 years? (hiding scientific information- "The Apprentice")

"...They decided to settle the political conflict between them with biological weapons and they decided to kill innocent people for their political interests. Scientists, who later learned that the virus they produced would be used for this purpose, began to feel guilty. But they did nothing..." (using science for political gain, "Biological Weapon")

\section{Discussion and Conclusion}

The use of SF stories in science education offers students creative and imaginative ways to develop their understanding of the NOS, as well as scientific and technological concepts. The present study explores the potential for using SF stories written by PSTs in a content-specific course. This section discusses how the specific nature of SF could enrich science education. We wish to focus on one of the most important aspects of SF, which begs the question of "what if?". Czerneda (2006) has suggested that SF sparks readers' curiosity about what could happen if a certain aspect of science or technology existed (or did not exist). Thus, the SF genre could guide students to consider future or alternative world(s) alongside imaginary aspects of science and technology. SF asserts that today's imagination could become tomorrow's reality. Students should understand the thin line between science, imagination, and possibilities to have a better understanding of the future. To illustrate this idea, some of the stories ("Russian Team," "Blue Nightmare," and "The Apprentice") reflected the theme of a protagonist who developed superpowers. The writers of these stories sought answers to the question of "What if a child gained a superpower? What would he or she do?" This process could help students to think about the possibilities of a future different from their current reality, based on scientific content. When the PSTs wrote a SF story about this question, they were speculating about a situation that could happen in the future. For example, the hit 1970's series Six Million Dollar Man told a similar story about a former astronaut with bionic implants, which gave him superhuman strength, speed, and vision. While this show was considered a total fiction in those years, the Neuralink Corporation, founded by Elon Musk, recently announced plans to make this dream a reality by implanting paralyzed patients with electrodes to help them control computers or smartphones with their minds (Erika, 2020). Thus, it is reasonable to assert that SF stories can serve as a foundation for students to understand, think about, or even shape the future world.

SF also helps students to make sense of today's world. As the COVID-19 pandemic began spreading at the beginning of 2020, our lives began resembling SF. 
People tried to understand the pandemic by gathering and consuming information from different sources, including the SF genre. A recent study has shown that people's interest in SF movies about pandemics has increased drastically since 2019 (Doherty \& Giordano, 2020). SF about such a global problem can attract students' attention and create awareness in science lessons. The use of SF in lessons helps students to understand and internalize chaotic situations through these stories. Moreover, these types of stories offer different ways for science teachers to address controversial issues (e.g., vaccination hesitancy) in their teaching. Indeed, one of the stories ("Star Nightmare") had echoes of the current pandemic, painting a picture of an epidemic that appeared out of nowhere, causing people to suddenly become ill and die. This fictional story could provide students with the opportunity to think more deeply about the pandemic they are experiencing. This process is critical to making informed decisions on issues related to the pandemic.

The SF genre often involves unlikely scenarios with the potential to cause devastating consequences. Naturally occurring events provide another example of scenarios with the potential for catastrophe (Mackey \& Levan, 2019). This study also included examples of dystopian depictions of the future world or an alternative world ("Manipulator," "Recurrence," "From Future to Past," and "A Strange Story"). These stories largely illustrate worst-case scenarios related to the end of the world. As depicted in "A Strange Story," an alien taking a child to its home planet pushes the boundaries of imagination and creativity, as it is unlikely to happen in the present scientific reality. On the other hand, the story also depicts major current environmental problems that could bring about an end to life as we know it. The use of such elements can create awareness in students and guide them to make informed decisions on global problems as responsible active citizens in the future.

SF also familiarizes students with the ethical and societal aspects of scientific and technological terrain (Miller \& Bennett, 2008). Some of the stories ("Biological Weapon," "Russian Team," and "From Turkey to Mars") involved a struggle for authority between groups of people with different agendas. These authority figures had good and bad motives that could lead them to unethical behavior. Other stories ("Longing for Alistair" and "The Future in the Past") highlighted the characters' own internal conflicts that led them to unethical behavior. These kinds of stories can be used as a starting point for discussing ethical issues in science. For example, in "Longing for Alistair," one may ask about the ethical and moral implications of the behavior of a scientist who changed the normal cycle of the world to reunite with his dead wife. This fictional question could spark discussion on unethical behaviors and practices in real-world scientific practice.

The PSTs involved in the study had never participated in a classroom story writing activity before, which may explain the inadequacy of the plot structures in most of the stories. Most of the stories resembled popular books and movies (e.g., Arrival, X-Men, Iron Man, Back to the Future, The Hunger Games, the Divergent series), which was an indicator of the lack of originality. This result echoes a similar finding in the literature. In their study, Reis and Galvão (2007) observed that SF stories written by pre-service teachers reflected catastrophic scenarios and stereotypes depicted in films, television programs, and books. Since the writing activity helped the participants to learn about the SF genre and writing, they discovered new ways 
to show their understanding of the NOS and scientific processes. However, the limited depictions of the technological concepts in the stories demonstrated that more attention should be given to exploring technologies in the science classroom.

The results of the study have some implications for future studies and the use of SF stories in teaching practice. Language is critical for promoting scientific literacy of students, but it is often neglected in teacher education and science classrooms. Also, science teachers usually view science as an empirical and practical discipline and ignore its language-based nature. Teachers' own learning experiences as students have an influence on their instructional decisions in science classrooms. In that sense, science teacher education programs should provide PSTs with opportunities to learn science through the use of nontraditional literacy-based activities such as imaginative and creative writing tasks. We aimed to exemplify this idea by presenting a case of an SF story writing activity. The study presents an overview of the use and assessment of SF stories in the Science, Technology, and Society course. The evaluation rubric can be used in other courses and classroom settings to examine both literary aspects of stories and the specific features of the SF genre. Moreover, the SF genre illustrates the social, economic, ethical, and moral aspects of science for students and teachers alike. Future work could investigate how these aspects of SF develop students' moral reasoning and decision-making on SSIs.

There are a few limitations of the study that should be addressed when interpreting and applying its results. We have provided detailed descriptions and exemplars related to the coding process. However, the scoring criteria for the rubric entail making inferences on the part of other researchers to utilize them. Also, the study is limited by the relatively low number of stories generated by the participants. Even though the generalizability of the findings is limited, the study provides rich and in-depth descriptions of the stories. Another limitation of the study is that it focused only on the stories themselves, without investigating the PSTs' opinions of and experiences with the writing process. Future work should gather and analyze the participants' views to gain more in-depth information about their writing experiences, as well as their conceptions of the NOS and technology.

Supplementary Information The online version contains supplementary material available at https://doi. org/10.1007/s10763-021-10244-4.

\section{References}

Anthony, R. J., Tippett, C. D., \& Yore, L. D. (2010). Pacific CRYSTAL project: Explicit literacy instruction embedded in middle school science classrooms. Research in Science Education, 40(1), 45-64. https://doi.org/10.1007/s11165-009-9156-7.

Attebery, B. (2003). The magazine era: 1926-1960. In E. James \& F. Mendelsohn (Eds.), The Cambridge companion to science fiction (pp. 32-47). Cambridge University Press.

Avraamidou, L., \& Osborne, J. (2009). The role of narrative in communicating science. International Journal of Science Education, 31(12), 1683-1707. https://doi.org/10.1080/09500690802380695.

Barnett, M., \& Kafka, A. (2007). Using science fiction movie scenes to support critical analysis of science. Journal of College Science Teaching, 36(4), 31-35.

Bixler, A. (2007). Teaching evoluation with the aid of science fiction. The American Biology Teacher, 69(6), 337-340. https://doi.org/10.1662/0002-7685(2007)69[337:TEWTAO]2.0.CO;2. 
Campbell, J. L., Quincy, C., Osserman, J., \& Pedersen, O. K. (2013). Coding in-depth semistructured interviews: Problems of unitization and intercoder reliability and agreement. Sociological Methods \& Research, 42(3), 294-320. https://doi.org/10.1177/0049124113500475.

Choi, A., Notebaert, A., Diaz, J., \& Hand, B. (2010). Examining arguments generated by year 5, 7, and 10 students in science classrooms. Research in Science Education, 40(2), 149-169. https://doi.org/10. 1007/s11165-008-9105-x.

Corbin, J., \& Strauss, A. (2014). Basics of qualitative research: Techniques and procedures for developing grounded theory (4th ed.). Sage.

Czerneda, J. E. (2006). Science fiction \& scientific literacy. The Science Teacher, 73(2), 38-42.

Doherty, J., \& Giordano, J. (2020). What we may learn-and need-from pandemic fiction. Philosophy, Ethics, and Humanities in Medicine, 15(4), 1-3. https://doi.org/10.1186/s13010-020-00089-0.

Eilks, I., \& Hofstein, A. (2017). Curriculum development in science education. In K. S. Taber \& B. Akpan (Eds.), Science education: New directions in mathematics and science education (pp. 167181). Sense Publishers. https://doi.org/10.1007/978-94-6300-749-8_13.

Erika, P. (2020). Bionic man: Elon Musk creating 'six million dollar man implant chips' that enables paralyzed people to walk. The Science Times. https://www.sciencetimes.com/articles/26062/20200 615/bionic-man-elon-musk-creating-six-million-dollar-implant-chips.htm.

Fensham, P. (2001). Science as story: Science education by story. Asia-Pacific Forum on Science Learning and Teaching, 2(1), 1-5.

Freeman, G., \& Taylor, V. (2006). Integrating science and literacy instruction: A framework for bridging the gap. Rowman \& Littlefield Education.

Fulmer, G. W., Hwang, J., Ding, C., Hand, B., Suh, J. K., \& Hansen, W. (2021). Development of a questionnaire on teachers' knowledge of language as an epistemic tool. Journal of Research in Science Teaching, 58(4), 459-490. https://doi.org/10.1002/tea.21666.

Gunel, M., Hand, B., \& Prain, V. (2007). Writing for learning in science: A secondary analysis of six studies. International Journal of Science and Mathematics Education, 5(4), 615-637. https://doi. org/10.1007/s10763-007-9082-y.

Hadzigeorgiou, Y., Fokialis, P., \& Kabouropoulou, M. (2012). Thinking about creativity in science education. Creative Education, 3(5), 603-611. https://doi.org/10.4236/ce.2012.35089.

Halliday, M. A. K., \& Martin, J. R. (2003). Writing science: Literacy and discursive power. Routledge.

Hand, B., \& Prain, V. (2002). Teachers implementing writing-to-learn strategies in junior secondary science: A case study. Science Education, 86(6), 737-755. https://doi.org/10.1002/sce.10016.

Hand, B., \& Prain, V. (2006). Moving from border crossing to convergence of perspectives in language and science literacy research and practice. International Journal of Science Education, 28(2-3), 101-107. https://doi.org/10.1080/09500690500336528.

Hand, B., Prain, V., \& Yore, L. (2001). Sequential writing tasks' influence on science learning. In P. Tynjälä, L. Mason, \& K. Lonka (Eds.), Writing as a learning tool: Integrating theory and practice (pp. 105-129). Springer. https://doi.org/10.1007/978-94-010-0740-5_7.

Hand, B. M., Alvermann, D. E., Gee, J., Guzzetti, B. J., Norris, S. P., Phillips, L. M., Prain, V., \& Yore, L. D. (2003). Message from the "Island Group": What is literacy in science literacy? Journal of Research in Science Teaching, 40(7), 607-615. https://doi.org/10.1002/tea.10101.

Hand, B., Cavagnetto, A., \& Norton-Meier, L. (2019). Immersive approaches to science argumentation and literacy: What does it mean to "live" the languages of science? In V. Prain \& B. Hand (Eds.), Theorizing the future of science education research (pp. 99-113). Springer. https://doi.org/10.1007/ 978-3-030-24013-4_7.

Kelly, D. L., Centurino, V. A. S., Martin, M. O., \& Mullis, I. V. S. (2020). TIMSS 2019 encyclopedia: Education policy and curriculum in mathematics and science. Boston College, TIMSS \& PIRLS International Study Center. https://timssandpirls.bc.edu/timss2019/encyclopedia/.

Klassen, S., \& Froese Klassen, C. (2014a). Science teaching with stories: Theoretical and practical perspectives. In M. R. Matthews (Ed.), International handbook of research in history, philosophy and science teaching (pp. 1503-1529). Springer. https://doi.org/10.1007/978-94-007-7654-8_47.

Klassen, S., \& Froese Klassen, C. (2014b). The role of interest in learning science through stories. Interchange, 45(3-4), 133-151. https://doi.org/10.1007/s10780-014-9224-4.

Lederman, N. G., Abd-El-Khalick, F., Bell, R. L., \& Schwartz, R. S. (2002). Views of nature of science questionnaire: Toward valid and meaningful assessment of learners' conceptions of nature of science. Journal of Research in Science Teaching, 39(6), 497-521. https://doi.org/10.1002/tea.10034.

Liberko, C. A. (2004). Using science fiction to teach thermodynamics: Vonnegut, ice-nine, and global warming. Journal of Chemical Education, 81(4), 509-512. https://doi.org/10.1021/ed081p509. 
Mackey, D. A., \& Levan, K. (2019). Moral dilemmas and worst-case scenarios: Using post-apocalyptic fiction to teach criminal justice ethics. Journal of Criminal Justice Education, 30(3), 319-332. https://doi.org/10.1080/10511253.2018.1489974.

Menadue, C. B. (2017). Trysts tropiques: The torrid jungles of science fiction. Etropic, 16, 125-140. https://doi.org/10.25120/etropic.16.1.2017.3570.

Menadue, C. B., \& Cheer, K. D. (2017). Human culture and science fiction: A review of the literature, 1980-2016. SAGE Open, 7(3), 1-15. https://doi.org/10.1177/2158244017723690.

Metin, D., Cakiroglu, J., \& Leblebicioglu, G. (2020). Perceptions of eighth graders concerning the aim, effectiveness, and scientific basis of pseudoscience: The case of crystal healing. Research in Science Education, 50(1), 175-202. https://doi.org/10.1007/s11165-017-9685-4.

Miller, C. A., \& Bennett, I. (2008). Thinking longer term about technology: Is there value in science fiction-inspired approaches to constructing futures? Science and Public Policy, 35(8), 597-606. https:// doi.org/10.3152/030234208X370666.

Ministry of National Education. (2018). Fen bilimleri dersi öğretim programı (İlkokul ve ortaokul 3, 4, 5, 6, 7 ve 8. siniflar) [Science curriculum for primary and elementary levels 3, 4, 5, 6, 7, and 8. grades]. Republic of Turkey Ministry of National Education.

Murmann, M., \& Avraamidou, L. (2014). Narrative as a learning tool in science centers: Potentials, possibilities and merits. Journal of Science Communication, 13(2), 1-16. https://doi.org/10.22323/2. 13020202.

Namdar, B., \& Shen, J. (2016). Intersection of argumentation and the use of multiple representations in the context of socioscientific issues. International Journal of Science Education, 38(7), 1100-1132. https://doi.org/10.1080/09500693.2016.1183265.

National Research Council. (1996). National science education standards. National Academy Press.

National Research Council. (2012). A framework for K-12 science education: Practices, crosscutting concepts, and core ideas. The National Academies Press.

Norris, S. P., \& Phillips, L. M. (2003). How literacy in its fundamental sense is central to scientific literacy. Science Education, 87(2), 224-240. https://doi.org/10.1002/sce.10066.

Önen Öztürk, F. (2017). The impact of science-fiction movies on the self-efficacy perceptions of their science literacy of science teacher candidates. Educational Sciences: Theory \& Practice, 17, 1573-1603. https://doi.org/10.12738/estp.2017.5.0058.

Organization for Economic and Co-operation and Development. (2016). PISA 2015 assessment and analytical framework: Science, reading, mathematic and financial Literacy. Author. https://doi.org/10. 1787/9789264255425-en.

Orthia, L. A. (2015). Science fiction. In R. Gunstone (Ed.), Encyclopedia of science education (pp. 899902). Springer. https://doi.org/10.1007/978-94-007-2150-0_329.

Prain, V. (2006). Learning from writing in secondary science: Some theoretical and practical implications. International Journal of Science Education, 28(2-3), 179-201. https://doi.org/10.1080/09500 690500336643.

Putt, S. (2011). Using science fiction to teach science facts (Publication No. 263) [Master of Art Thesis, Minnesota State University]. All Graduate Theses, Dissertations, and Other Capstone Projects. http://cornerstone.lib.mnsu.edu/etds/263.

Pytash, K. E. (2013). Secondary preservice teachers' development of teaching scientific writing. Journal of Science Teacher Education, 24(5), 793-810. https://doi.org/10.1007/s10972-013-9338-z.

Reis, P., \& Galvão, C. (2004). Socio-scientific controversies and students' conceptions about scientists. International Journal of Science Education, 26(13), 1621-1633. https://doi.org/10.1080/09500 69042000205413.

Reis, P., \& Galvão, C. (2007). Reflecting on scientists' activity based on science fiction stories written by secondary students. International Journal of Science Education, 29(10), 1245-1260. https://doi.org/ 10.1080/09500690600975340.

Ritchie, S. M., Tomas, L., \& Tones, M. (2011). Writing stories to enhance scientific literacy. International Journal of Science Education, 33(5), 685-707. https://doi.org/10.1080/09500691003728039.

Roberts, A. (2006). The history of science fiction. Palgrave Macmillan. https://doi.org/10.1057/97802 30554658.

Roberts, D. A. (2007). Scientific literacy/science literacy. In S. K. Abell \& N. G. Lederman (Eds.), Handbook of research on science education (pp. 729-780). Lawrence Erlbaum Associates.

Selwyn, N., Pangrazio, L., Nemorin, S., \& Perrotta, C. (2020). What might the school of 2030 be like? An exercise in social science fiction. Learning, Media and Technology, 45(1), 90-106. https://doi. org/10.1080/17439884.2020.1694944. 
Sha, R. C. (2012). Volta's battery, animal electricity, and Frankenstein. European Romantic Review, 23(1), 21-41. https://doi.org/10.1080/10509585.2012.639182.

Sterling, B. (2021). Science fiction. Encyclopedia Britannica. https://www.britannica.com/art/sciencefiction.

Surmeli, H. (2012). Examination the effect of science fiction films on science education students' attitudes towards STS course. Procedia-Social and Behavioral Sciences, 47, 1012-1016. https://doi. org/10.1016/j.sbspro.2012.06.771.

van den Akker, J. (1999). Principles and methods of development research. In J. van den Akker, R. M. Branch, K. Gustafson, N. Nieveen, \& T. Plomp (Eds.), Design approaches and tools in education and training (pp. 1-14). Springer. https://doi.org/10.1007/978-94-011-4255-7_1.

Vrasidas, C., Avraamidou, L., Theodoridou, K., Themistokleous, S., \& Panaou, P. (2015). Science fiction in education: Case studies from classroom implementations. Educational Media International, 52(3), 201-215. https://doi.org/10.1080/09523987.2015.1075102.

Williams, C. T., \& Rudge, D. W. (2019). Effects of historical story telling on student understanding of nature of science. Science \& Education, 28(9), 1105-1133. https://doi.org/10.1007/ s11191-019-00073-x.

Yin, R. K. (2003). Case study research: Design and methods (3rd ed.). Sage.

Yore, L. D. (2012). Science literacy for all-more than a slogan, logo, or rally flag! In K. C. D. Tan \& M. Kim (Eds.), Issues and challenges in science education research: moving forward (pp. 5-23). Springer. https://doi.org/10.1007/978-94-007-3980-2_2.

Yore, L. D. (2018). Commentary on the expanding development of literacy research in science education. In K. S. Tang \& K. Danielsson (Eds.), Global developments in literacy research for science education (pp. 379-397). Springer. https://doi.org/10.1007/978-3-319-69197-8_22.

Yore, L. D., \& Treagust, D. F. (2006). Current realities and future possibilities: Language and science literacy-empowering research and informing instruction. International Journal of Science Education, 28(2-3), 291-314. https://doi.org/10.1080/09500690500336973.

Yore, L., Bisanz, G. L., \& Hand, B. M. (2003). Examining the literacy component of science literacy: 25 years of language arts and science research. International Journal of Science Education, 25(6), 689-725. https://doi.org/10.1080/09500690305018. 